\title{
Managing Your Brand for Employees: Understanding the Role of Organizational Processes in Cultivating Employee Brand Equity
}

\section{Ezgi Erkmen}

School of Tourism and Hospitality, Laureate International Universities, İstanbul Bilgi University, Eski Silahtarağa Elektrik Santralı, Kazım Karabekir Cad. No: 2/13, 34060 Eyüpsultan İstanbul, Turkey; ezgi.erkmen@bilgi.edu.tr; Tel.: +90-532-446-8319

Received: 24 July 2018; Accepted: 6 September 2018; Published: 8 September 2018

\begin{abstract}
The purpose of this study was to understand how employee brand equity is cultivated in services. Specifically, a conceptual model, adopted from brand equity literature, was developed and tested to analyze the internal brand building process. To achieve this, a quantitative research methodology, using structural equation modeling, was used to understand the role of brand building mechanisms, namely the internal communication, external communication, and employee experience with the brand, in building employee brand equity. As a part of the service industry, data were collected from hotel employees who have direct contact with customers. The findings evidenced the distinguished role of each mechanism to build employee brand equity. That is, while internal communication enhances brand knowledge and role clarity, external communication and employee experience with the brand positively affect the brand commitment of employees. Therefore, as being the first study adopting customer service brand equity to employee context, this research confirmed the effect of brand building mechanisms on employee brand equity. In addition, the study proposes practical implications for organizations to design a balanced branding approach both internally and externally through the means of communication.
\end{abstract}

Keywords: brand management; brand communication; brand experience; employee brand equity

\section{Introduction}

Brands represent a sum of functional and emotional attributes. In other words, a brand combines functional and emotional values to deliver a promise about the brand experience (De Chernatony and Segal-Horn 2001). Therefore, the success of a brand depends on how well the brand delivers its values as promised. However, the delivery of brand values is more challenging for services. First, services usually represent performances or experiences, which are difficult to evaluate due to the intangible nature of the offering (Zeithaml and Bitner 1996). Thus, it is more difficult to communicate brand values to customers. Moreover, due to inseparability of production and consumption, employees providing the service are usually considered to be the service itself. Lastly, it is difficult to achieve standardization in services because service delivery depends on the performance of the employees (Zeithaml and Bitner 1996). That is, the consistent delivery of both functional and emotional values depends on the interaction between employees and consumers (De Chernatony and Segal-Horn 2001). Therefore, it is from this perspective that the branding of services requires an approach different from branding of physical goods. Since service organizations heavily depend on employees to deliver the brand promise, there is an increasing concern over managing their brand related attitudes and behaviors. As a result, internal branding, which is about aligning employee behaviors with the brand promise, has been introduced to the branding literature. The ultimate purpose of internal branding is 
to ensure the emotional and intellectual staff buy-in (Thomson et al. 1999). That is, all internal branding efforts are directed to create a strong brand equity for employees.

First introduced by King et al. (2012, p. 269), employee brand equity is "the differential effect that brand knowledge has on an employee's response to internal brand management". However, how staff becomes aware of the brand values is still a critical question for researchers (De Chernatony et al. 2006). This being the case, the concept of brand equity has magnified its importance as a requirement for successful internal brand management. Conversely, the brand equity literature is still dominated by two commonly adopted perspectives: customer based and financial based brand equity. It is for this reason that King and Grace (2009) came up with the need for a third perspective. In their pioneering research, the authors proposed "employee based brand equity", which focuses on brand knowledge as being the key for internal brand building efforts.

Despite the introduction of the concept and the shift towards adopting a third perspective for brand equity, to date, most research has studied the concept conceptually or theoretically (De Chernatony et al. 2006; King and Grace 2008, 2009, 2010). In addition, as stated by King et al. (2012), few studies have empirically examined what constitutes employee brand equity as well as how it is cultivated. Lastly, Piehler et al. (2015) noted that internal brand management requires a more detailed investigation of specific mechanisms, such as internal communication and external communication, for their effect on employee-related outcomes.

As argued by De Chernatony et al. (2006), communication of brand values, both internally and externally, is the key to building employee brand. However, communication requires more than codifying the brand. That is, how the brand values are experienced is also important to increase the credibility of the codified brand messages (Lencioni 2002). Therefore, the purpose of this study was to propose and test an employee based service brand equity model that explains how internal brand equity is cultivated for employees. To achieve its purpose, the current research leveraged the Berry (2000) service-branding model to build a new conceptual framework and hypotheses related to the means by which brand information dissemination effects brand equity of service employees. To do so, the hospitality industry, due to its intense dependence on employees to deliver the brand values, was chosen as a part of the service sector.

Consequently, the findings of this study have substantive contributions both for the literature and for practice. First, this paper extends the current literature on internal branding by providing empirical evidence about how communicating brand values cultivate employee brand equity. Second, this paper is the first to adopt the service brand equity model to internal branding context. That is, the research offers an alternative framework to understand the brand-building process internally. Finally, the results will also aid practitioners to understand how dissemination of brand information affects brand related attitudes and behaviors of employees. More specifically, industry professionals may get insight into the effects of different communication mechanisms on specific dimensions of employee brand equity. Thus, this will help managers to design their internal branding activities more effectively.

\section{Review of Literature}

\subsection{Services Branding and Brand Equity}

Traditionally, a brand has been defined as "a name, term, sign, symbol, or design, or a combination of them, intended to identify the goods and services of one seller or group of sellers and to differentiate them from those of competitors" (Keller 2003, p. 3). However, in the last decades, researchers noted that, although the definition works well for physical goods, services require a more strategic conceptualization (De Chernatony et al. 2003; Gronroos 2007; Skaalsvik and Olsen 2014). That is, the distinguished characteristics of services, namely the intangibility, inseparability of production and consumption, heterogeneity, and perishability, necessitate a different approach for services branding (De Chernatony and Segal-Horn 2001). 
Built upon these arguments, Jacobs (2003, p. 24) came up with a new definition of branding, proposing that "branding is more than a company logo or tagline, but it is the company's promise. Similarly, Bergstrom et al. (2002, p. 134) defined brand as "the sum total of all perceived functional and emotional aspects of a product or service" and the activity of branding as "about adding a higher level of emotional meaning to a product or service, thereby increasing its value to customers and other stakeholders". Nevertheless, although literature offers different definitions of branding, the common point for both physical goods and services is to develop a strong brand equity by creating value for different stakeholders (Berry 2000).

Since the ultimate purpose of all branding efforts is to create a strong brand equity (Kim et al. 2003), the concept has received a great attention of both academicians and practitioners. However, most studies have conceptualized the brand equity either form a financial or customer perspective. While financial brand equity is defined as "the total value of brand which is separable asset-when it is sold or includes in the balance sheet" (Atilgan et al. 2005, p. 238), customer brand equity is defined as the "the differential effect of brand knowledge on consumer response to the marketing of the brand" (Keller 1993, p. 8). Hence, whichever perspective is adopted, brand equity is the "added value" to a product or service (Chaudhuri 1995).

Despite the increased focus on the concept of brand equity, few studies have tried to understand the "added value" of a product or service from the employee perspective. To address this paucity, King and Grace (2009) proposed a third approach, employee based brand equity. The idea behind the proposition is that the branding of services starts from inside and employees are the key to brand success (De Chernatony et al. 2006). That is, besides customers and shareholders, service brand equity literature should account for the other stakeholders, namely the employees. Consequently, recent literature has started to promote the view of employee brand equity as the starting point for brand building process and tried to assess the value of the brand for employees.

\subsection{Employee Based Brand Equity}

With the shift from an external view to inside-out marketing view, service companies have started to consider customer contact employees as being internal customers (Yang et al. 2015). Therefore, brand equity from the perspective of employees, which is a measure of internal branding efforts, has started to gain attention. King et al. (2012, p. 269), who came up with the need of a third approach, defined the concept as "the differential effect that brand knowledge has on an employee's response to internal brand management". Drawing on the conceptualization of customer-based brand equity (Keller 1993), King and Grace (2010) proposed brand knowledge to be the driving force for employee brand equity. That is, the main idea of King and Grace's approach (King and Grace 2010) is that a strong brand equity results from brand knowledge effects, which are role clarity and brand commitment.

According to Keller (2003, p. 596), brand knowledge is "the personal meaning about a brand stored consumer memory, that is, all descriptive and evaluative brand-related information". Even the definition addresses the consumers; the concept is also equally relevant for employees because having brand knowledge is the foundation to develop brand equity (Backhaus and Tikoo 2004). In other words, employees who have the appropriate brand knowledge, are more likely to understand their roles and deliver the expected brand promise (Ambler 2003; Mangold and Miles 2007; King and Grace 2010). Thus, brand knowledge with a clear understanding helps employees to overcome the uncertainty and to become committed to the brand (De Chernatony and Segal-Horn 2001; De Chernatony and Cottam 2006).

Regarding the uncertainty, providing employees sufficient knowledge about brand expectations would enhance their role clarity or decrease their role ambiguity. More specifically, role clarity represents a way for organizations to assess the effect of brand knowledge (King and Grace 2005). If employees are clearly informed about brand values and expectations, they will be more likely to internalize the values and pass these values on to customers (Punjaisri and Wilson 2007). Moreover, 
employees who are aware of and confident about their roles would be more like to develop an attachment to the company and to the brand (Mukherjee and Malhotra 2006).

Given the importance of developing attachment, Burmann and Zeplin (2005, p. 284) came up with employee brand commitment and defined the concept as "the extent of psychological attachment of employees to the brand, which influences their willingness to exert extra effort towards reaching the brand goals". In line with this definition, Kimpakorn and Tocquer (2009, p. 533) conceptualized brand commitment as "the degree to which employees identify and are involved with their service brand, are willing to exert additional efforts to achieve the goals of the brand and are interested in remaining with the service organization". Built upon these definitions, commitment is clearly the key dimension in determining brand equity (Ambler 2003). As proposed by Aurand et al. (2005), employees with a high degree of brand commitment are more likely to internalize and realize the brand values.

As evidenced by the previous discussions, provision of brand knowledge enables employees to have clarity about brand expectations. Further, if employees appreciate the information disseminated regarding the brand values, they will develop a sense of attachment to the brand. Therefore, acknowledging that brand knowledge is central to brand equity, this study also adopts the conceptualization of King and Grace (2009) suggesting brand knowledge, role clarity, and brand commitment as the dimensions of the concept. However, the suggested brand equity concept does not occur in isolation. That is, brand-building processes shape all cognitive responses of employees to the brand. As such, understanding the process of how employee based brand equity is ensured by the service organizations is crucial for in-depth understanding of internal brand management.

\subsection{Employee Based Brand Equity Process}

It is obvious that building brand equity largely depends on the dissemination of information. One of the key points for the success of service branding is to ensure that customer contact employees deliver the brand promise as expected. Therefore, based on the commonly held view that employees could be the starting point for brand equity, it is appropriate to understand how employee based brand equity is built within the organizations. One way service firms could assure the consistent delivery of the brand is to transform brand information to employees (King and Grace 2010; Piehler et al. 2015).

As stated earlier, brands represent the sum of functional and emotional values to various stakeholders (De Chernatony et al. 2006). Therefore, it is important to know what the literature means with the term "value". In its formal definition, a value is "an enduring belief that a specific mode of conduct or end-state of existence is personally or socially preferable to an opposite or converse mode of conduct or end-state of existence" (Rokeach 1973, p. 5). As result, it is reasonable to assume that corporate brand values can shape brand related attitudes and behaviors of employees. That is, to enable employees to have a strong brand equity, brand meaning and values need to be communicated to employees (King and Grace 2008).

Therefore, to understand how brand equity is built through information, previous studies on branding have mostly adopted Aaker (1991) framework for brand equity. However, the proposed model of brand equity does not address the needs of services branding (So and King 2010). In addition, the framework does not clearly answer the process of building brand equity. As a result, to address this paucity, Keller (1998) proposed a new model focusing on brand knowledge related to both product and services. While the new conceptualization has answered the specific needs of services to some extent, the foundation of the model is still manufacture based (So and King 2010).

To overcome these drawbacks in previous frameworks, Berry (2000) came up with a new brand equity model specifically for service organizations. While Berry (2000) framework has conceptualized brand equity as the sum of brand awareness and brand meaning, the author also explained the process of how the brand equity is cultivated. That is, the company's presented brand, external brand communications, and customer experience with the company are identified as the sources of information. More specifically, these three factors form the brand knowledge driving customer brand equity. 
Even the proposed framework is developed for the customer perspective; this paper argues that it could be equally applicable to employee brand equity for two reasons. First, employees, especially the customer contact employees, are considered internal customers for organizations (Ambler 2003). Second, brand knowledge is also considered the driving force behind employee brand equity (King and Grace 2010). As a result, with some alterations, this research adopted Berry (2000) model to understand the process of building brand equity. While the company's presented brand was measured by internal communication directed to employees, external communications were used in the original form including public relations and word of mouth. On the other hand, customer experience with the brand was replaced with brand as experienced by employees offered by Kimpakorn and Tocquer (2009).

As suggested by the above conceptualization, communication is the key to understanding the process of building brand internally. Therefore, how brand values are communicated to staff requires special attention. Recent research has studied the effect of internal communication on employees' brand related attitudes and behaviors, however the major drawback of these studies is considering the communication from an internal perspective. More specifically, research has usually focused on internal communication mechanisms and ignored the role of external corporate communication (De Chernatony et al. 2006).

Based on the internal communication perspective, a brand is communicated to employees both explicitly and implicitly (Lings et al. 2008). On the one hand, organizations can communicate information explicitly to employees through human resources activities or organizational directives. On the other hand, behaviors of managers or other employees could implicitly transform brand values (Hoogervorst et al. 2004). Therefore, corporate communication activities explicitly directed to employees represent the formal internal communication mechanisms. The implicit communication forms the context in which employees interpret explicit communication. In other words, it is the context how employees experience the brand (Kimpakorn and Tocquer 2009). Experienced brand by employees basically refers to employee experience on the job resulting from day to day activities of the organization. Therefore, how employees experience the brand is especially important to ensure the psychological attachment of the employees. As employees perceive consistency between communicated values and behaviors aligned with these values, they would be more likely to be committed to the brand (Mangold and Miles 2007). In other words, employees usually compare their actual experiences with the espoused brand values to check for any incongruence. As such, brand experience resulting from implicit communication has been included as one of the factors affecting employee brand equity.

Even though internal communication, either explicit or implicit, represents a crucial process to transform brand values to employees, it leads to a significant drawback, when considering a comprehensive approach to developing employee brand equity. It is for this reason that Miles and Mangold (2004) and Piehler et al. (2015) emphasized the importance of external communications, namely the public relations and word of mouth, as the other sources of brand messages for employees. While public relation activities are the formal sources of information generated by companies to shape the brand image of different stakeholders, word of mouth refers to informal information from outside parties (Kotler 2003). Therefore, from internal branding perspective, employees are the secondary recipient of external information (Miles and Mangold 2004). Similarly, De Chernatony et al. (2006) argued that external marketing communications are one of the information sources enabling service employees to become aware of brand values.

Why communication locates at the heart of the brand equity has also been well documented in other studies. That is, the research promoting the importance of communication identified a variety of positive outcomes for brand building efforts of companies. Through effective communication of brand, organizations can create a shared understanding of the brand (Aurand et al. 2005; Burmann et al. 2009; Punjaisri et al. 2009; Xiong et al. 2013). This, in turn, enhances employee brand knowledge as well as brand commitment (Lings et al. 2008; Punjaisri and Wilson 2007; Yang et al. 2015). Moreover, communication related to the brand helps employees to understand better the expectations regarding 
brand promise. Therefore, information dissemination also results in a better understanding of employees' role in brand delivery (King and Grace 2005; Piehler et al. 2015).

Whether internal or external, the ultimate purpose of all these communication efforts is to enhance brand knowledge of employees, which is the key for branding activities. As suggested by Keller (1998), brand knowledge represents a node in the memory consisting of associations related to the brand. As such, these associations in the memory influence people's behaviors and attitudes regarding a company brand. Even though brand knowledge first emerged for consumers, King and Grace (2009) argued that it is equally relevant for employees. While brand knowledge is used to create the brand identity to reflect the consumption behaviors of consumers, it is used to create the brand identity to endanger brand-related work behaviors of employees. Therefore, employee based brand equity is about identification based relationship of employees with the brand (King and Grace 2009). Specifically, there are two perspectives, which are social-exchange based and organizational-identification based relationships, to explain the employer-employee relationship in the literature. Social-exchange based perspective is evolved from social-exchange theory, which explains employee relationship through the exchange of materialistic resources. In contrast, identification based relationship is based on social identity theory explaining employee relationship through fit between personal identity and organizational identity (Ashforth and Mael 1989). Developed by Tajfel and Turner (1986), social identity theory helps to understand the mental processes that people go through when identifying their group membership. The idea behind the theory is that being a part of the group provides people with a sense of belonging and a social identity. As a result, based on the social identity theory, King and Grace (2009) came up with the concept of employee based brand equity. That is, from the perspective of branding, brand identification of employees helps to increase their feeling of distinctiveness and oneness due to being a part of the brand (Bergstrom et al. 2002). Specifically, identification with the brand provides necessary knowledge about the desired brand promise (Miles and Mangold 2004). Furthermore, with such an identification, employees better understand their roles with a clear direction (Tosti and Stotz 2001). Lastly, brand identification of employees enhances their attachment through the feeling of distinctiveness and oneness due to being a part of the brand (Bergstrom et al. 2002). It is from this perspective that this study also adopted the identification based employee brand equity developed by King and Grace (2009) and created its own following conceptual model (see Figure 1) to test the proposed hypotheses.

H1a: Internal communication positively affects brand knowledge.

H2a: Internal communication positively affects role clarity.

H3a: Internal communication positively affects brand commitment.

H1b: External communication positively affects brand knowledge.

H2b: External communication positively affects role clarity.

H3b: External communication positively affects brand commitment.

H1c: Company brand as experienced by employees positively affects brand knowledge.

H2c: Company brand as experienced by employees positively affects role clarity.

H3c: Company brand as experienced by employees positively affects brand commitment.

\section{Methods}

\subsection{Instrument and Measures}

Data were collected via a self-administered structured questionnaire. All items, other than demographic factors, were measured using a five-point Likert-type scale $(1=$ strongly disagree to $5=$ strongly agree). The survey instrument consisted of three major sections. The first two sections included questions related to brand building mechanisms and brand equity, respectively. The measurement scales for internal communication (Punjaisri and Wilson 2007), external communication (Bansal and Voyer 2000), company brand as experienced by employees (Kimpakorn and Tocquer 2009), 
employee brand knowledge (Kimpakorn and Tocquer 2009), role clarity (Mukherjee and Malhotra 2006), and brand commitment (King and Grace 2010) were adopted from previous multi-item scales. The third section asked about the demographic profile of respondents.

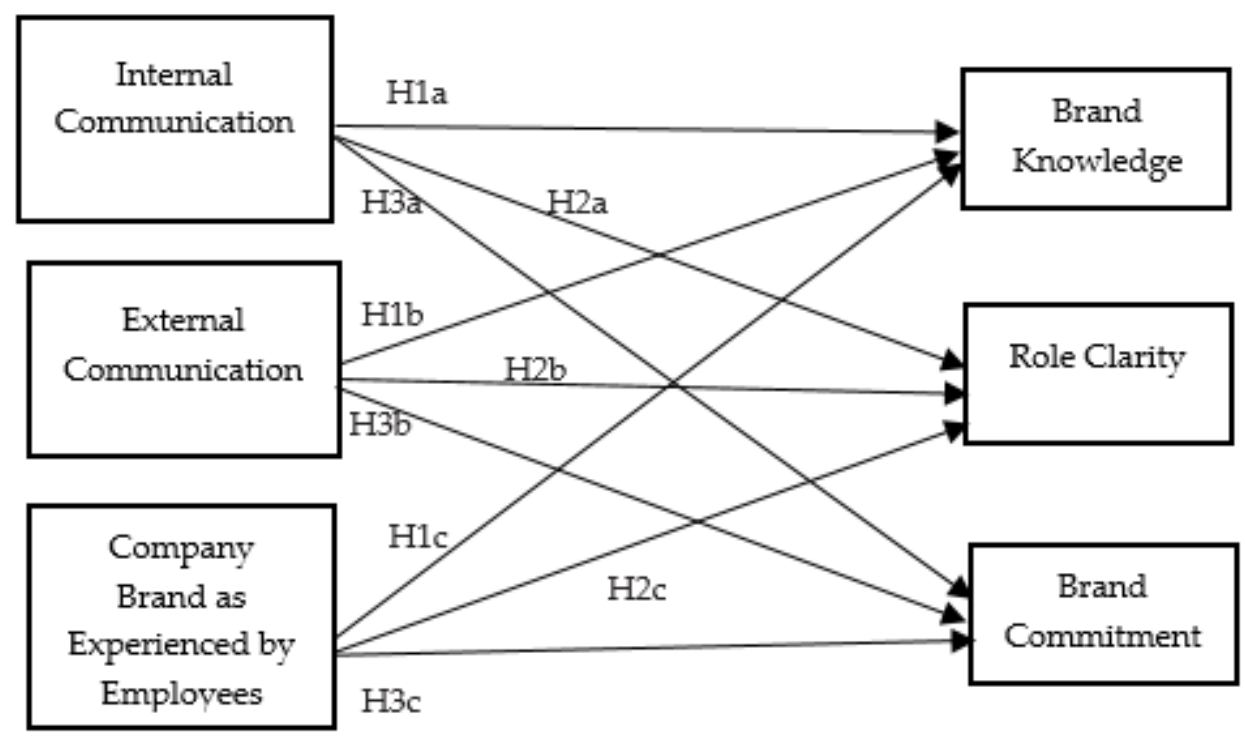

Figure 1. Proposed conceptual model of the study.

\subsection{Sampling}

The target population of this research was the hotel employees who have direct contact with guests and who are working in five-star hotels in Istanbul. A convenience sampling method was used to obtain data about employees' perception of the brand. Finally, the study obtained 374 usable questionnaires for the data analysis.

\subsection{Data Analysis}

First, this study used the statistical package SPSS 20.0 to obtain the frequencies of demographic characteristics as well as the descriptive statistics of observed variables. Second, confirmatory factor analysis (CFA) was conducted to test the measurement model and to assess the reliability and validity of the scale items. Lastly, the hypothesized relationships were analyzed through structural equation modeling (SEM) by using Mplus7.

\section{Results}

\subsection{Demographic Profile of Respondents}

Table 1 shows the demographic profile of respondents participated in the study. Among the 374 service employees, males represented $60.4 \%$ and females represented $39.6 \%$ of the sample. Most of the respondents were between the ages of 18 and 25 followed by the age groups of $26-35$ (34.5\%), 36-45 $(20.9 \%)$, and 46 or above $(5.3 \%)$. The majority of the respondents $(57.8 \%)$ were single, while $42.2 \%$ were married. With regard to education level, nearly $57 \%$ completed either a pre-college or a bachelor degree. Together, high school and graduate degree holders accounted for the remaining $43 \%$. 
Table 1. Demographic profile of respondents.

\begin{tabular}{cccc}
\hline Variable & & $\mathbf{N}$ & $\%$ \\
\hline \multirow{3}{*}{ Gender } & Male & 226 & 60.4 \\
& Female & 148 & 39.6 \\
& Total & 374 & 100 \\
\hline \multirow{4}{*}{ Age } & $18-25$ & 147 & 39.3 \\
& $26-35$ & 129 & 34.5 \\
& $36-45$ & 78 & 20.9 \\
& 46 or above & 20 & 5.3 \\
& Total & 374 & 100 \\
\hline \multirow{3}{*}{ Marital Status } & Single & 216 & 57.8 \\
& Married & 158 & 42.2 \\
& Total & 374 & 100 \\
\hline \multirow{4}{*}{ Education Level } & High School & 132 & 35.3 \\
& Pre-College & 47 & 12.6 \\
& Bachelor & 167 & 44.7 \\
& Graduate & 28 & 7.4 \\
& Total & 374 & 100 \\
\hline
\end{tabular}

\subsection{Measurement and Structural Model}

The proposed conceptual model was tested by confirmatory factor analysis followed by structural equation modeling using Satorra-Bentler procedure in Mplus (Satorra and Bentler 2001) due to its advantage of being robust against non-normality and multicollinearity. The overall model fit indices for the CFA satisfied the recommended cut-off points (comparative fit index $(\mathrm{CFI})=0.910$; Tucker-Lewis index $(\mathrm{TLI})=0.904$; standardized root mean residual $(\mathrm{SRMR})=0.074$; and root mean square error of approximation (RMSEA) $=0.042$ ), representing a good fit of the model to the data based on the minimum cut-off values of CFI $\geq 0.90$, TLI $\geq 0.90$, SRMR $\leq 0.08$, and RMSEA $\leq 0.08$, respectively, as suggested by Hooper et al. (2008). Next, estimates of the reliability and variance extracted measures for each construct were checked to assess measurement quality (see Tables 2 and 3). All factor loadings exceeding critical t-value of 2.576 at $p<0.01$ for each variable were statistically significant satisfying convergent validity. Internal consistency was also checked through composite reliability (CR) and average variance extracted (AVE) scores. All constructs met the recommended level of 0.70 for CR and 0.50 for AVE indices. Moreover, the average of AVE for each pair of constructs was greater than their squared correlation. Therefore, the discriminant validity was evidenced for the measurement scale. Lastly, the study conducted Harman's single factor test to check common method bias due to self-reported data collected through the same questionnaire during the same period with cross-sectional research design. Since the total variance for the single factor was found to be $16 \%$, which is less than $50 \%$, common method bias was not evidenced for the study.

Table 2. Construct correlations and Average Variance Explained.

\begin{tabular}{ccccccc}
\hline & \multicolumn{7}{c}{ Cross-Construct Correlations } \\
\hline Measurement Scale & 1 & 2 & 3 & 4 & 5 & 6 \\
Internal communication & 1.00 & 0.428 & 0.384 & 0.219 & 0.475 & 0.126 \\
External communication & & 1.00 & 0.546 & 0.489 & 0.248 & 0.401 \\
Brand as experienced by employees & & & 1.00 & 0.236 & 0.274 & 0.265 \\
Role clarity & & & & & 1.00 & 0.541 \\
Brand Commitment & & & & & 0.00 & 1.00 \\
Average Variance Extracted (AVE) & 0.53 & 0.58 & 0.45 & 0.67 & 0.59 & 0.55 \\
\hline
\end{tabular}


Table 3. Measurement model results.

\begin{tabular}{|c|c|c|c|c|c|}
\hline Construct & Mean & SD & AVE & $\begin{array}{l}\text { Composite } \\
\text { Reliability }\end{array}$ & $\begin{array}{l}\text { Standardized } \\
\text { Factor Loadings }\end{array}$ \\
\hline Internal Communication & & & 0.53 & 0.82 & \\
\hline IC1 & 3.7080 & 0.9130 & & & 0.723 \\
\hline IC2 & 3.6903 & 0.8246 & & & 0.638 \\
\hline IC3 & 3.5487 & 0.8659 & & & 0.720 \\
\hline IC4 & 3.0531 & 0.8539 & & & 0.678 \\
\hline External Communication & & & 0.58 & 0.90 & \\
\hline EC1 & 3.8230 & 1.0956 & & & 0.739 \\
\hline EC2 & 3.8142 & 1.0982 & & & 0.738 \\
\hline EC3 & 3.5310 & 1.0109 & & & 0.707 \\
\hline EC4 & 3.8407 & 1.0737 & & & 0.764 \\
\hline EC5 & 3.8053 & 1.1008 & & & 0.672 \\
\hline EC6 & 2.6903 & 0.6557 & & & 0.716 \\
\hline EC7 & 2.7168 & 0.6334 & & & 0.629 \\
\hline EC8 & 3.6195 & 0.6473 & & & 0.652 \\
\hline EC9 & 2.7699 & 0.6815 & & & 0.669 \\
\hline EC10 & 3.6018 & 0.8918 & & & 0.653 \\
\hline Brand as Experienced by Employees & & & 0.45 & 0.89 & \\
\hline BE1 & 4.5752 & 0.4965 & & & 0.708 \\
\hline BE2 & 4.5310 & 0.5012 & & & 0.621 \\
\hline BE3 & 4.5575 & 0.4988 & & & 0.682 \\
\hline $\mathrm{BE} 4$ & 4.5398 & 0.5006 & & & 0.649 \\
\hline BE5 & 4.5221 & 0.5017 & & & 0.657 \\
\hline BE6 & 4.0442 & 0.7949 & & & 0.586 \\
\hline BE7 & 3.9292 & 0.7643 & & & 0.530 \\
\hline BE8 & 3.1593 & 0.8608 & & & 0.585 \\
\hline BE9 & 4.0088 & 0.8072 & & & 0.579 \\
\hline BE10 & 4.4159 & 0.4950 & & & 0.647 \\
\hline BE11 & 3.1416 & 0.4934 & & & 0.564 \\
\hline BE12 & 4.5310 & 0.5012 & & & 0.606 \\
\hline BE13 & 4.3178 & 0.7548 & & & 0.649 \\
\hline BE14 & 4.4071 & 0.4934 & & & 0.576 \\
\hline Brand Knowledge & & & 0.67 & 0.93 & \\
\hline BK1 & 3.1327 & 0.8399 & & & 0.548 \\
\hline BK2 & 3.3009 & 0.7056 & & & 0.972 \\
\hline BK3 & 3.3363 & 0.7147 & & & 0.764 \\
\hline BK4 & 3.3540 & 0.6670 & & & 0.648 \\
\hline BK5 & 3.3451 & 0.7412 & & & 0.767 \\
\hline BK6 & 3.2478 & 0.7137 & & & 0.802 \\
\hline BK7 & 3.2743 & 0.7588 & & & 0.917 \\
\hline Role Clarity & & & 0.59 & 0.92 & \\
\hline $\mathrm{RC} 1$ & 4.4867 & 0.5020 & & & 0.800 \\
\hline $\mathrm{RC} 2$ & 4.6549 & 0.4775 & & & 0.795 \\
\hline $\mathrm{RC} 3$ & 4.4248 & 0.4965 & & & 0.771 \\
\hline $\mathrm{RC} 4$ & 4.5929 & 0.4934 & & & 0.759 \\
\hline $\mathrm{RC5}$ & 4.4779 & 0.5017 & & & 0.768 \\
\hline RC6 & 3.4425 & 0.4988 & & & 0.788 \\
\hline $\mathrm{RC7}$ & 3.5664 & 0.4977 & & & 0.753 \\
\hline $\mathrm{RC} 8$ & 3.5221 & 0.5017 & & & 0.764 \\
\hline Brand Commitment & & & 0.55 & 0.86 & \\
\hline BC1 & 3.5664 & 0.4977 & & & 0.753 \\
\hline $\mathrm{BC} 2$ & 4.4956 & 0.4625 & & & 0.750 \\
\hline $\mathrm{BC} 3$ & 4.4690 & 0.5012 & & & 0.763 \\
\hline $\mathrm{BC} 4$ & 4.5044 & 0.5356 & & & 0.657 \\
\hline BC5 & 4.4810 & 0.5012 & & & 0.720 \\
\hline
\end{tabular}


After assessing the measurement quality of the model, the conceptual model was tested according to Anderson and Gerbing (1988). The results of the overall model (comparative fit index (CFI) = 0.923; Tucker-Lewis index $(\mathrm{TLI})=0.917$; standardized root mean residual $(\mathrm{SRMR})=0.063$; and root mean square error of approximation $($ RMSEA $)=0.040$ ) were satisfactory, indicating a good fit for the data. The results of the hypothesized paths are provided in Table 4. Regarding the effect of internal communication on employee brand equity, the results confirm the hypothesized effects on brand knowledge and role clarity (H1a, $\gamma 11=0.839, \mathrm{t}=7.384, p<0.01 ; \mathrm{H} 2 \mathrm{a}, \gamma 12=0.799, \mathrm{t}=8.363$, $p<0.01$ ). Internal communication explained $87 \%$ of the variance for brand knowledge and $76 \%$ of the variance for role clarity. However, the effect of internal communication on brand commitment was not significant $(\mathrm{H} 3 \mathrm{a}, \gamma 13=0.054, \mathrm{t}=1.854, p>0.05)$. Regarding the effect of external communication on brand equity, only one path, which suggests a positive influence on brand commitment, was significant $(\mathrm{H} 3 \mathrm{~b}, \gamma 23=0.379, \mathrm{t}=4.145, p<0.01)$. However, the study results did not confirm a positive effect on brand knowledge and role clarity, thereby failing to support $\mathrm{H} 1 \mathrm{~b}$ and $\mathrm{H} 2 \mathrm{~b}$. Lastly, for the hypothesized effects of the brand as experienced by employees, only the proposed impact on brand commitment was supported $(\mathrm{H} 3 \mathrm{c}, \gamma 23=0.629, \mathrm{t}=8.256, p<0.01)$. Regarding the explained variance, external communication and brand as experienced by employees have accounted for $83 \%$ of the variance for brand commitment. Therefore, overall, the results have only supported the positive effects of internal communication on brand knowledge and role clarity-external communication on brand commitment—and brand as experienced on brand commitment.

Table 4. Results of path analysis.

\begin{tabular}{lllcc}
\hline \multicolumn{1}{c}{ Path to } & \multicolumn{1}{c}{ Path from } & \multicolumn{1}{c}{$\mathbf{H}_{\mathbf{0}}$} & Std. Coeff. & t-Value \\
\hline Brand Knowledge & Internal & H1a: Supported & 0.839 & $7.484^{* *}$ \\
Role Clarity & Communication & H2a: Supported & 0.799 & $8.363^{* *}$ \\
Brand Commitment & & H3a: Not Supported & 0.054 & 1.854 \\
\hline Brand Knowledge & External & H1b: Not Supported & 0.098 & 1.281 \\
Role Clarity & Communication & H2b: Not Supported & 0.122 & 1.734 \\
Brand Commitment & & H3b: Supported & 0.379 & $4.145^{* *}$ \\
\hline Brand Knowledge & Brand as & H1c: Not Supported & 0.106 & 1.386 \\
Role Clarity & Experienced by & H2c: Not Supported & 0.086 & 1.295 \\
Brand Commitment & Employees & H3c: Supported & 0.629 & $8.256^{* *}$ \\
\hline
\end{tabular}

Note. ${ }^{*} p<0.05,{ }^{* *} p<0.01$.

\section{Discussion and Implications}

\subsection{Discussion of the Findings}

Despite the increased attention of academicians to extend brand equity concept to employees, there appears to be a lack of empirical studies to understand how employee brand equity is cultivated. As such, this study is the first to apply Berry's customer brand equity model (Berry 2000) to employee context building upon the theoretical framework of King and Grace (2009). In doing so, the research has contributed to the existing knowledge on employee branding in different ways. First, the present research has provided an alternative framework supported by empirical evidence to understand the internal brand building process. Second, this study has integrated the role of external communication, which has been widely ignored in previous internal branding studies (De Chernatony et al. 2006). That is, recent studies have usually focused on the internal communication to examine the brand building process (Aurand et al. 2005; Burmann et al. 2009) Moreover, in contrast to the current literature, this study has also investigated the role of all kinds of communication, both explicit and implicit, to provide deeper insight into the internal branding.

Overall, the findings suggest that the proposed mechanisms have different roles in building brand equity for employees. Specifically, as expected, internal communication positively affects brand knowledge and role clarity for employees. This result confirms the findings of previous studies 
(De Chernatony et al. 2006; Welch and Jackson 2007; Tsai et al. 2010) noting that communicating brand internally clarifies the brand expectations and values through increasing brand understanding. However, this research could not establish a significant link between internal communication and brand commitment. This is somewhat surprising given the contrary results in the literature (Lings et al. 2008; Burmann et al. 2009; Punjaisri and Wilson 2011; Yang et al. 2015). One possible reason for this finding is that, although internal communication affects brand knowledge and role clarity, brand commitment requires a psychological attachment to the brand (Burmann and Zeplin 2005). That is, commitment requires not only receiving information but also internalizing that information. Therefore, as suggested by Mitchell (2002), even messages can transmit the brand expectations, higher level of internalization is achieved when the messages are reinforced by the organizational system. This interpretation is also consistent with Lencioni (2002) who argued for living the values by involvement rather than just codifying these values in brand messages.

Furthermore, contrary to internal communication, the results of the study validate the positive influences of external communication and brand as experienced by employees on brand commitment. Such a result is largely in line with recent propositions of conceptual studies (Miles and Mangold 2004; De Chernatony et al. 2006; Piehler et al. 2015) suggesting external communication as being one of the tools to enhance commitment. On the other hand, this research could not support the hypothesized positive effect of external communication on brand knowledge and role clarity. Hence, the finding contradicts with the studies arguing that external communication increases brand understanding (De Chernatony et al. 2006; Piehler et al. 2015). Similarly, even how employees experience the brand is found to have a significant impact on brand commitment as noted by Kimpakorn and Tocquer (2009), the effects on brand knowledge and role clarity are insignificant. These findings can be explained based on the arguments for internalization and the signaling role of the brand. First, as suggested by Miles and Mangold (2004), once employees have experienced messages consistent with internal messages, such experience leads to higher level of internalization. Moreover, based on the signaling theory (Spence 1973), company communications provide cues as information signals about the value of an intangible service offering (Brodie et al. 2009). That is, when employees perceive brand signals to be credible, they are more likely to internalize the brand-related information (Xiong et al. 2013). Lastly, given the commonly accepted view that internalization is the key to brand commitment (Burmann and Zeplin 2005), the positive influence of employee brand experience on commitment is not surprising. As employees experience brand values that are consistent with brand information provided, they would be more likely to believe in the brand and develop an attachment to that brand.

In summary, the insight of this research lies in its attempt to understand how brand equity is cultivated through proposed mechanisms. However, the study also has its own limitations. First, the study was conducted in the hospitality industry lowering the external validity of the findings. Second, convenience sampling used in this research might affect the representativeness of the sample for the entire population. Hence, generalizing the results and making inferences about the population poses a limitation for the present research. Third, the participants were asked to indicate their self-reported attitudes regarding scale items. Therefore, it is difficult to guarantee that participants truly reflected their own attitudes and beliefs. Lastly, this study did not investigate all factors, which might be affecting the brand equity of employees. That is, specific working conditions (Hur and Adler 2011), employee-organization fit, employee know-how, and organizational resources (Burmann et al. 2009; King and Grace 2009) might moderate the effect of suggested factors on employee based brand equity. As such, future research could benefit from understanding the role of other factors in developing brand equity for employees. Furthermore, the proposed model might be tested in other industries for the external validity of the findings.

\subsection{Theoretical Contributions}

This study contributed to the existing knowledge of employee brand equity in the service industry in different ways. First, the research is the first to adopt the service brand equity model of Berry (2000) 
to the employee brand equity context. To date, most previous literature analyzes the employee brand equity conceptually or theoretically (De Chernatony et al. 2006; King and Grace 2008, 2009, 2010). However, this study provided empirical support for the role of proposed mechanisms in cultivating brand equity for employees. Second, the other important theoretical contribution is the integration of external communications to explain its effect on internal brand building. That is, on the one hand, recent research mostly focuses on the role of internal communications to explain brand related behaviors and attitudes of employees (Burmann et al. 2009; Punjaisri and Wilson 2011; Baker et al. 2014). On the other hand, the research acknowledging the importance of external communication studies the construct conceptually (De Chernatony et al. 2006; Piehler et al. 2015). Thus, the results have provided empirical support for the effect of external communication on building brand internally. Lastly, in addition to communication, the study also tried to understand how employees' experience with the brand influences their brand equity. Brand as experienced by employees refers to "the way in which employees experience the brand in their daily work. (Kimpakorn and Tocquer 2009, p. 535). Therefore, the results of this study have developed the understanding of internal brand building via going beyond communicating brand values. That is, the results provided support how experience with the brand in the daily work life contributes internal brand building process.

\subsection{Practical Implications}

From the practical perspective, this study acknowledges the fact that building brand internally requires a balanced brand management approach focusing on both internal and external mechanisms. The results suggest that internal communication of the brand both increases employees brand knowledge and helps them to understand their roles clearly for the effective delivery of brand promise. To achieve this, organizations need to create a brand-oriented structure, in which both explicit and implicit messages are reinforced by the organizational system. While explicit communication is about codifying and disseminating brand information through formal channels, implicit communication is about the actions (Lings et al. 2008). Therefore, human resources activities, namely the orientation and training, as well as the behaviors of managers and employees should be aligned with the intended brand identity. One of the techniques could be corporate storytelling (Gill 2011), which helps to share information with employees and increase the meaningfulness of the messages. This, in turn, leads to a higher level of internalization of the brand. Furthermore, brand communication should not be limited to only orientation and training, but needs to be extended to recruitment processes. In other words, human resources should also inform the potential employees. As such, potential employees could able to assess their fit with the company brand beforehand and to judge whether it is the right place for employment.

In line with the previous arguments, the companies also need to recognize the importance of employees' experience with the brand. That is, as the major source of implicit communication through their behaviors, managers should act as a role model by reflecting brand values both verbally and nonverbally. Subsequently, organizations could achieve a consistent delivery of the brand both explicitly and implicitly. As the results suggest, employees experience with the brand is one of the major contributors of the brand commitment.

Lastly, this study indicates that external communication activities are also important to create brand equity not only externally but also internally. In particular, companies need to consider their employees "second audience" (George and Berry 1981, p. 52). Similar to customers, they are also exposed to external information, which, in turn, affects their perception of the company brand. Therefore, this finding implies that all communication activities either internal or external should be consistent. Otherwise, the discrepancy between the internal and external information would diminish the effect of internal branding activities. It is from this perspective that organizations should not adopt branding strategies that are different for customers and employees. As argued by Backhaus and Tikoo (2004), developing brand for employees does not mean creating a separate brand identity for employees. Therefore, external communication needs to target both customers and employees 
to create a unique brand identity. In designing their branding and marketing activities, companies would be better to create messages that appeal to all stakeholders, especially to the customers and employees. Furthermore, even traditional organizational structures assume human resources as the primary department being responsible for the internal brand management, the findings show that employees experience with the brand through implicit communication results in a higher level of attachment to the brand. That is, employee brand commitment could be enhanced through managers' adherence and support for the brand. Moreover, as suggested by the results, external communication also serves as an important mean to influence employees' commitment. Therefore, organizations would be better to adopt a balanced brand management approach including human resources, marketing, and supervisors of employees. As all functions of the organizations adopt a more comprehensive approach, employees would be able to have a better brand experience, which, in turn, leads to a better brand experience for customers. Hence, a strong internal brand equity could be used to ensure a strong external brand equity.

To sum up, organizations need to consider the brand-building process as a loop where there is no starting point or ending point. More specifically, an integrated marketing approach to branding leads employees to deliver a brand promise consistent with external marketing information. Then, successful delivery of the brand results in positive feedback and word of mouth from the customer, which, in turn, further enhances brand equity and brand-related employee behaviors.

Funding: This research received no external funding.

Conflicts of Interest: The author declares no conflict of interest.

\section{References}

Aaker, David A. 1991. Managing Brand Equity. New York: Free Press.

Ambler, Tim. 2003. Marketing and the Bottom Line: The Marketing Metrics to Pump up Cash Flow. London: Pearson Education.

Anderson, James C., and David W. Gerbing. 1988. Structural equation modeling in practice: A review and recommended two-step approach. Psychological Bulletin 103: 411. [CrossRef]

Ashforth, Blake E., and Fred Mael. 1989. Social identity theory and the organization. Academy of Management Review 14: 20-39. [CrossRef]

Atilgan, Eda, Şafak Aksoy, and Serkan Akinci. 2005. Determinants of the brand equity: A verification approach in the beverage industry in Turkey. Marketing Intelligence amd Planning 23: 237-48. [CrossRef]

Aurand, Timothy W., Linda Gorchels, and Terrence R. Bishop. 2005. Human resource management's role in internal branding: An opportunity for cross-functional brand message synergy. Journal of Product E Brand Management 14: 163-69.

Backhaus, Kristin, and Surinder Tikoo. 2004. Conceptualizing and researching employer branding. Career Development International 9: 501-17. [CrossRef]

Baker, Thomas L., Adam Rapp, Tracy Meyer, and Ryan Mullins. 2014. The role of brand communications on front line service employee beliefs, behaviors, and performance. Journal of the Academy of Marketing Science 42: 642-57. [CrossRef]

Bansal, Harvir S., and Peter A. Voyer. 2000. Word-of-mouth processes within a services purchase decision context. Journal of Service Research 3: 166-77. [CrossRef]

Bergstrom, Alan, Dannielle Blumenthal, and Scott Crothers. 2002. Why internal branding matters: The case of Saab. Corporate Reputation Review 5: 133-42. [CrossRef]

Berry, Leonard L. 2000. Cultivating service brand equity. Journal of the Academy of Marketing Science 28: 128-37. [CrossRef]

Brodie, Roderick J., James R. M. Whittome, and Gregory J. Brush. 2009. Investigating the service brand: A customer value perspective. Journal of Business Research 62: 345-55. [CrossRef]

Burmann, Christoph, and Sabrina Zeplin. 2005. Building brand commitment: A behavioral approach to internal brand management. Journal of Brand Management 12: 279-300. [CrossRef] 
Burmann, Christoph, Sabrina Zeplin, and Nicola Riley. 2009. Key determinants of internal brand management success: An exploratory empirical analysis. Journal of Brand Management 16: 264-84. [CrossRef]

Chaudhuri, Arjun. 1995. Brand equity or double jeopardy? Journal of Product E Brand Management 4: 26-32.

De Chernatony, Leslie, and Susan Cottam. 2006. Internal brand factors driving successful financial services brands. European Journal of Marketing 40: 611-33. [CrossRef]

De Chernatony, Leslie, and Susan Segal-Horn. 2001. Building on services' characteristics to develop successful services brands. Journal of Marketing Management 17: 645-69. [CrossRef]

De Chernatony, Leslie, Susan Drury, and Susan Segal-Horn. 2003. Building a services brand: Stages, people and orientations. Service Industries Journal 23: 1-21. [CrossRef]

De Chernatony, Leslie, Susan Cottam, and Susan Segal-Horn. 2006. Communicating services brands' values internally and externally. The Service Industries Journal 26: 819-36. [CrossRef]

George, William R., and Leonard L. Berry. 1981. Guidelines for the advertising of services. Business Horizons 24: 52-56. [CrossRef]

Gill, Rob. 2011. Using storytelling to maintain employee loyalty during change. International Journal of Business and Social Science 2: 23-32.

Gronroos, Christian. 2007. Service Management and Marketing: Customer Management in Service Competition. Chichester: Wiley.

Hoogervorst, Jan, Henk van der Flier, and Paul Koopman. 2004. Implicit communication in organizations: The impact of culture, structure and management practices on employee behavior. Journal of Managerial Psychology 19: 288-11. [CrossRef]

Hooper, Daire, Joseph Coughlan, and Michael Mullen. 2008. Structural equation modelling: Guidelines for determining model fit. The Electronic Journal of Business Research Methods 6: 53-60.

Hur, Yoonkyung, and Howard Adler. 2011. Employees' perceptions of restaurant brand image. Journal of Foodservice Business Research 14: 334-59. [CrossRef]

Jacobs, Rick. 2003. Turn employees into brand ambassadors. ABA Bank Marketing 35: 22.

Keller, Kevin Lane. 1993. Conceptualizing, measuring, and managing customer-based brand equity. The Journal of Marketing, 1-22. [CrossRef]

Keller, Kevin Lane. 1998. Strategic Brand Management. Upper Saddle River: Prentice Hall.

Keller, Kevin Lane. 2003. Brand synthesis: The multidimensionality of brand knowledge. Journal of Consumer Research 29: 595-600. [CrossRef]

Kim, Hong-Bumm, Woo Gon Kim, and Jeong A. An. 2003. The effect of consumer-based brand equity on firms' financial performance. Journal of Consumer Marketing 20: 335-51. [CrossRef]

Kimpakorn, Narumon, and Gerard Tocquer. 2009. Employees' commitment to brands in the service sector: Luxury hotel chains in Thailand. Journal of Brand Management 16: 532-44. [CrossRef]

King, Ceridwyn, and Debra Grace. 2005. Exploring the role of employees in the delivery of the brand: A case study approach. Qualitative Market Research: An International Journal 8: 277-95. [CrossRef]

King, Ceridwyn, and Debra Grace. 2008. Internal branding: Exploring the employee's perspective. Journal of Brand Management 15: 358-72. [CrossRef]

King, Ceridwyn, and Debra Grace. 2009. Employee based brand equity: A third perspective. Services Marketing Quarterly 30: 122-47. [CrossRef]

King, Ceridwyn, and Debra Grace. 2010. Building and measuring employee-based brand equity. European Journal of Marketing 44: 938-71. [CrossRef]

King, Ceridwyn, Debra Grace, and Daniel C. Funk. 2012. Employee brand equity: Scale development and validation. Journal of Brand Management 19: 268-88. [CrossRef]

Kotler, Philip. 2003. Marketing Management. Upper Saddle River: Prentice Hall.

Lencioni, Patrick M. 2002. Make your values mean something. Harvard Business Review 80: 113-17. [PubMed]

Lings, Ian, Amanda Beatson, and Siegfried Gudergan. 2008. The impact of implicit and explicit communications on frontline service delivery staff. The Service Industries Journal 28: 1431-43. [CrossRef]

Mangold, W. Glynn, and Sandra Jeanquart Miles. 2007. The employee brand: Is yours an all-star? Business Horizons 50: 423-33. [CrossRef]

Miles, Sandra Jeanquart, and Glynn Mangold. 2004. A conceptualization of the employee branding process. Journal of Relationship Marketing 3: 65-87. [CrossRef]

Mitchell, Colin. 2002. Selling the brand inside. Harvard Business Review 80: 99-101. [PubMed] 
Mukherjee, Avinandan, and Neeru Malhotra. 2006. Does role clarity explain employee-perceived service quality? A study of antecedents and consequences in call centers. International Journal of Service Industry Management 17: 444-73. [CrossRef]

Piehler, Rico, Stephan Hanisch, and Christoph Burmann. 2015. Internal branding—Relevance, management and challenges. Marketing Review St. Gallen 32: 52-61. [CrossRef]

Punjaisri, Khanyapuss, and Alan Wilson. 2007. The role of internal branding in the delivery of employee brand promise. Journal of Brand Management 15: 57-70. [CrossRef]

Punjaisri, Khanyapuss, and Alan Wilson. 2011. Internal branding process: Key mechanisms, outcomes and moderating factors. European Journal of Marketing 45: 1521-37. [CrossRef]

Punjaisri, Khanyapuss, Heiner Evanschitzky, and Alan Wilson. 2009. Internal branding: An enabler of employees' brand-supporting behaviors. Journal of Service Management 20: 209-26. [CrossRef]

Rokeach, Milton. 1973. The Nature of Human Values. New York: Free Press.

Satorra, Albert, and Peter M. Bentler. 2001. A scaled difference chi-square test statistic for moment structure analysis. Psychometrika 66: 507-14. [CrossRef]

Skaalsvik, Hugo, and Bjørn Olsen. 2014. Service branding: Suggesting an interactive model of service brand development. Kybernetes 43: 1209-23. [CrossRef]

So, Kevin, and Ceridwyn King. 2010. When experience matters: Building and measuring hotel brand equity: The customers' perspective. International Journal of Contemporary Hospitality Management 22: 589-608. [CrossRef]

Spence, Michael. 1973. Job market signaling. Uncertainty in Economics, 281-306. [CrossRef]

Tajfel, Henri, and John C. Turner. 1986. The Social Identity Theory of Intergroup Behaviour. u: Worchel S. i Austin WG (ur.) Psychology of Intergroup Relations. Chicago: Nelson Hall.

Thomson, Kevin, Leslie de Chernatony, Lorrie Arganbright, and Sajid Khan. 1999. The buy-in benchmark: How staff understanding and commitment impact brand and business performance. Journal of Marketing Management 15: 819-35. [CrossRef]

Tosti, Donald T., and Rodger D. Stotz. 2001. Brand: Building your brand from the inside out. Marketing Management 10: 28.

Tsai, Henry, Catherine Cheung, and Ada Lo. 2010. An exploratory study of the relationship between customerbased casino brand equity and firm performance. International Journal of Hospitality Management 29: 754-57. [CrossRef]

Welch, Mary, and Paul R. Jackson. 2007. Rethinking internal communication: A stakeholder approach. Corporate Communications: An International Journal 12: 177-98. [CrossRef]

Xiong, Lina, Ceridwyn King, and Rico Piehler. 2013. That's not my job: Exploring the employee perspective in the development of brand ambassadors. International Journal of Hospitality Management 35: 348-59. [CrossRef]

Yang, Jen-Te, Chin-Sheng Wan, and Chi-Wei Wu. 2015. Effect of internal branding on employee brand commitment and behavior in hospitality. Tourism and Hospitality Research 15: 267-80. [CrossRef]

Zeithaml, Valarie, and Mary Jo Bitner. 1996. Services Marketing. New York: McGraw Hill.

(C) 2018 by the author. Licensee MDPI, Basel, Switzerland. This article is an open access article distributed under the terms and conditions of the Creative Commons Attribution (CC BY) license (http://creativecommons.org/licenses/by/4.0/). 